\title{
Ekstraksi Minyak Atsiri Dari Bawang Merah Dengan Metode Microwave Ultrasonic Steam Diffusion (MUSDf)
}

\author{
Achmad Ferdiansyah ${ }^{*}$, Islamiyah Wulandari, Nadya Rosita Asri \\ Departemen Teknik Kimia Industri, Insitut Teknologi Sepuluh Nopember (ITS). Kampus ITS Sukolilo, \\ Surabaya ${ }^{1}$ Departemen Teknik Kimia Industri, Insitut Teknologi Sepuluh Nopember (ITS). Kampus \\ ITS Sukolilo, Surabaya
}

*Penuiis korespondensi: ach ferdi@chem-eng.its.ac.id

\begin{abstract}
This research, the shallot extraction process is done by Microwave Steam Diffusion method modified with the addition of ultrasonic. This method can produce product (yield) with high quality of essential shallot oil with lower processing energy requirement. The variables used are Microwave Steam Diffusion (MSDf) and Microwave Ultrasonic Steam Diffusion (MUSDf) with extraction time of 40, 50, 60 and 70 minutes. The result of this research, shows that the best method to produce red shallot oil extract is by using MUSDf method which has obtained yield of $0.96 \mathrm{ml} / \mathrm{kg}, 61.14 \%$ organosulfur and 60 minutes optimum time of extraction.
\end{abstract}

Keywords: : shallot, microwave, ultrasonic, oranosulfur.

\begin{abstract}
Abstrak
Penelitian ekstraksi bawang merah ini dilakukan dengan menggabungkan metode Microwave Steam Diffusion (MSDf) dengan penambahan gelombang ultrasonic. Penambahan ini bertujuan agar yield dan konsumsi energi yang dibutuhkan dalam proses ekstraksi bawang merah menurun. Variabel yang digunakan pada penelitian ini adalah metode MSDf dan metode MUSDf (Microwave Ultrasonic Steam Diffusion) yang diberi penambahan gelombang ultrasonic. Waktu ekstraksi pada penelitian ini adalah 40, 50, 60 dan 70 menit. Hasil yang didapat adalah metode terbaik untuk mendapatkan minyak atsiri dari bawang merah adalah metode MUSDf dengan yield sebesar $0,96 \mathrm{ml} / \mathrm{kg}$ dan kadar organo sulfur sebesar $61,14 \%$, serta waktu ekstraksi yang optimum adalah 60 menit.
\end{abstract}

Kata kunci: bawang merah, microwave, ultrasonic, organosulfur.

\section{Pendahuluan}

Melimpahnya produksi bawang merah dengan rata-rata hasil panen pertahunnya mencapai 1,4 juta ton menyebabkan harga bawang merah turun yaitu Rp. 15 ribu per kg.
Namun, disaat tidak musim harga bawang merah melonjak tinggi yaitu Rp. 70 ribu per kg. Harga bawang merah yang cenderung fluktuatif menyebabkan kerugian bagi petani karena stok bawang merah yang tidak terjual 
menjadi busuk. Oleh karena itu, diperlukan inovasi pengolahan bawang merah dengan mengambil minyak atsirinya. Pengolahan bawang merah menjadi minyak atsiri bawang merah ini sangat penting untuk dilakukan agar saat panen raya petani tidak merugi karena harga yang rendah. Hal ini tentunya juga menjadi solusi untuk meningkatkan pendapatan petani bawang merah.

Minyak atsiri bawang merah termasuk minyak nabati yang memiliki karekter mudah menguap dengan aroma yang sangat khas. Minyak jenis ini sering disebut sebagai minyak eteris, minyak aromatik atau minyak terbang [1,2]. Bawang merah mengandung minyak atsiri yang terdiri atas Trans-2-ethyl2-butenal dan senyawa organosulfur [3].

Proses pengambilan minyak atsiri dari bawang merah sudah dikembangkan oleh peneliti sebelumnya. Salah satunya adalah penelitian dengan metode Supercritical $\mathrm{CO} 2$ Extraction Optimization of Onion Oil Using Response Surface Methodology diperoleh yield 3,01 $\mathrm{ml} / \mathrm{kg}$ dengan suhu operasi 40,60C selama 260 menit [4]. Pada metode ini, waktu yang dibutuhkan untuk menghasilkan minyak sangat lama serta teknologi yang digunakan sangat kompleks dan sulit diterapkan, kemudian metode lain yang lebih sederhana yaitu Coupling Pilot Extraction dan diperoleh yield sebesar 0,033 $\mathrm{ml} / \mathrm{kg}$. Metode ini dilakukan dengan suhu operasi yang cukup tinggi yaitu 1650C dalam waktu 15 menit. Kekurangan dari metode ini adalah yield yang dihasilkan rendah [5].

Oleh karena itu, inovasi modifikasi metode perlu dilakukan lebih lanjut terhadap ekstraksi minyak bawang merah. Metode yang akan dipakai pada penelitian ini adalah Microwave Steam Diffusion dengan penambahan gelombang ultrasonik yang bertujuan untuk menghasilkan minyak bawah merah dengan kualitas yang baik melalui proses yang lebih efisien dengan energi yang sedikit tetapi menghasilkan yield tinggi. Penelitian ini bertujuan menganalisis pengaruh penambahan gelombang ultrasonik terhadap yield minyak bawang merah pada metode Microwave Steam Diffusion. Menganalisis pengaruh penambahan gelombang ultrasonik terhadap kadar organosulfur pada metode Microwave Steam Diffusion. Menganalisis pengaruh penambahan gelombang ultrasonik terhadap konsumsi energi pada metode Microwave Steam Diffusion.

\section{Metodologi}

\subsection{Alat dan Bahan}

Bahan yang dipakai ialah bawang merah segar dan aquadest. Peralatan yang digunakan microwave, steam generator, dan ultrasonik. Ultrasonik digunakan untuk mempercepat proses ekstraksi minyak bawang merah dengan memperlebar pori-pori bawang merah. Spesifikasi dari ultrasonik dengan frekuensi $30 \pm 3 \mathrm{kHz}$, power supply 
input 220-240 Volt, dan output power 3-30 watt. Microwave digunakan sebagai penghasil panas pada proses ekstraksi. Spesifikasi dari microwave yaitu daya 450 watt. Steam Generator digunakan untuk menghasilkan uap air. Spesifikasi Steam Generator yaitu daya sebesar 1800 watt. Serangkain alat Microwave Ultrasonic Steam Diffusion (MUSDf) dapat dilihat pada Gambar 1.

\subsection{Eksraksi Minyak Bawang Merah dengan Metode MSDf dan MUSDf}

Bahan baku yang digunakan berupa bawang merah segar sebanyak 500 gram yang sudah dipotong kecil-kecil dan air sebanyak 500 mL. Ekstraksi minyak bawang merah dengan metode Microwave Steam Diffusion (MSDf) dilakukan maserasi selama 30 menit terlebih dahulu. Sedangkan untuk metode Microwave Ultrasonic Steam Diffusion (MUSDf) maserasi dilakukan dengan menambahan gelombang ultrasonic selama 30 menit. Setelah itu, dilakukan ekstraksi dengan metode MSDf dan dilanjutkan dengan metode MUSDf dengan waktu 40, 50, 60 dan 70 menit. Kemudian, minyak bawang merah yang dihasilkan akan dilanjutkan pada proses penghitungan yield dan karekterisasi minyak bawang merah dengan menggunakan uji GCMS untuk mengetahui senyawa organosulfur yang terkandung. Selain itu juga dihitung konsumsi energi dari masing-masing metode yang digunakan.

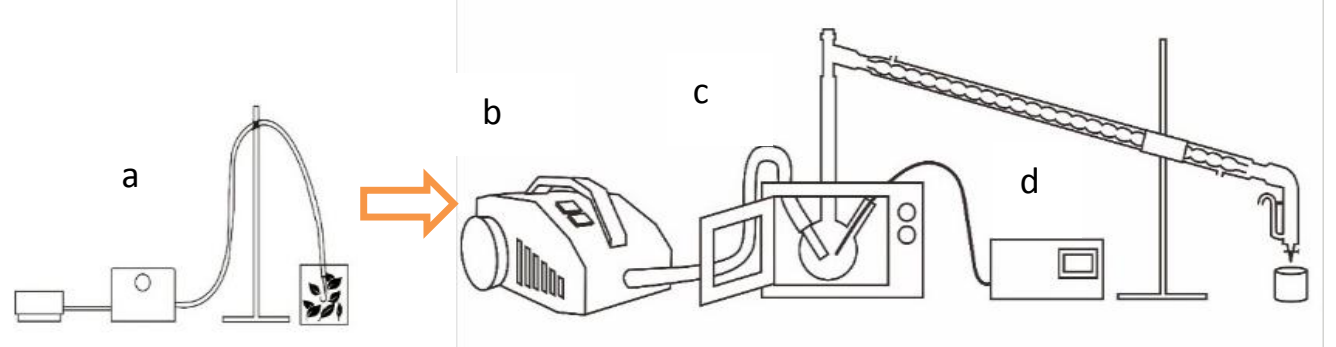

Gambar 1. a. Ultrasonic Sonode, b. Steam Generator, c. Microwave, d. Thermo Couple

\section{Hasil dan Pembahasan}

\subsection{Pengaruh Penambahan Ultrasonik}

Pada Metode MSDf terhadap Yield

\section{Minyak Bawang Merah}

Penambahan gelombang ultrasonik pada metode MSDf bertujuan agar yield yang dihasilkan dari proses ekstraksi ini semakin besar dengan waktu ekstraksi yang singkat. Teknologi ini sangat sesuai untuk mengekstrak bahan alam yang memiliki tingkat sensitivitas tinggi terhadap perubahan suhu. Pada subbab ini akan dilakukan analisis pengaruh penambahan ultrasonik pada metode MSDf terhadap yield minyak bawang 
merah. Performa yield yang dihasilkan dapat dilihat pada grafik 1 berikut :

Dari grafik 1. dapat dilihat bahwa yield $(\mathrm{ml} / \mathrm{kg})$ tertinggi pada metode MUSDf dan MSDf ditunjukkan pada menit ke 60 dan 70 sebesar $0,96 \quad \mathrm{ml} / \mathrm{kg}$ dan $0,80 \quad \mathrm{ml} / \mathrm{kg}$. Sedangkan yield terendah pada metode MUSDf dan MSDf ditunjukkan pada menit ke 40 sebesar $0,56 \mathrm{ml} / \mathrm{kg}$ dan $0,40 \mathrm{ml} / \mathrm{kg}$. Berdasarkan hal tersebut dapat dilihat waktu optimum untuk menghasilkan ekstrak dengan yield tertinggi pada metode MSDf dan MUSDf adalah pada waktu ke-60 menit dengan yield sebesar $0,96 \mathrm{ml} / \mathrm{kg}$ dan 0,80 $\mathrm{ml} / \mathrm{kg}$. Yield yang dihasilkan pada menit ke 60 dan 70 untuk kedua metode, sama karena minyak bawang merah yang terkandung didalam bahan sudah maksimum terekstrak dengan metode yang telah digunakan.

Selaput dinding sel dari bawang merah semakin lama semakin melunak berbanding lurus dengan lamanya waktu ekstraksi. Selain itu adanya perbedaan konsentrasi minyak bawang merah yang tinggi antara pelarut dengan bahan yang diekstrak menyebabkan semakin cepat yield yang didapatkan diawal proses ekstraksi. Selanjutnya penambahan waktu ekstraksi tidak berdampak terhadap yield yang didapatkan. Hal ini disebabkan oleh kandungan minyak bawang merah pada pelarut sudah semakin tinggi sehingga kemampuan untuk melarutkannya lagi semakin kecil. Selain itu juga, kandungan minyak yang terkandung di dalam bahan juga semakin kecil $[6,7]$.

Adanya peningkatan yield pada MUSDf disebabkan oleh gelombang ultrasonik yang ditambahkan selama proses maserasi. Energi dari gelombang ultrasonik ini akan melalui media air sebagai perantara untuk berkontak dengan bahan bawang merah. Gelombang ultrasonik yang memiliki energi ini akan menimbulkan fenomena kavitasi. Fenomena ini diawali dari terbentuknya gelembung kecil pada pelarut yang terus bertambah besar seiring dengan penambahan gelombang ultrasonik. Gelembung tersebut semakin lama semakin membesar dan pecah sehingga mengeluarkan energi yang besar [8]. Energi yang ditimbulkan ini dapat merusak dinding sel bawang merah sehingga bahan aktif yang ada di dalam sel mudah untuk keluar. Tahapan proses fenomena kavitasi ini dapat dilihat pada gambar 2 berikut.

Fenomena kavitasi ini sesuai dengan penjelasan pada penelitian Khan et al. (2010) tentang ekstraksi polyphenols dari kulit jeruk menggunakan Ultrasound-Assisted Extraction. Pada penelitian ini didapatkan simpulan bahwa penambahan gelombang ultrasonik mampu mempersingkat waktu ekstraksi. Hal ini disebabkan oleh adanya proses kavitasi selama proses sonifikasi yang berdampak pada pecahnya dinding sel yang 
memungkinkan terjadinya proses difusi menjadi lebih cepat.

Proses kavitasi tepat pada permukaan bahan bawang merah (a), lalu ukuran gelembung yang semakin membesar menyebabkan gelembung tersebut pecah dan menimbulkan tekanan yang tinggi (b dan c). Tekanan yang timbul berdampak pada pecahnya sel bawang merah dan kandungan minyak bawang merah terlepas ke pelarut (d) sehingga yield yang dihasilkan semakin besar [9].

$\begin{array}{rrr}\text { Penggunaan } & \text { ultrasonik dalam } \\ \text { proses ekstraksi } & \text { memiliki banyak }\end{array}$

kelebihan dibanding dengan ekstraksi konvensional. Kelebihannya antara lain adalah mempu mempercepat proses ekstraksi dan mampu mengurangi jumlah pelarut yang digunakan. Selain itu metode ini lebih aman digunakan untuk bahan yang memiliki sifat sensitif terhadap suhu (thermolabile) [10]. Berdasarkan penjelasan diatas dapat disimpulkan bahwa bahwa metode MUSDf lebih efisien daripada metode MSDf.

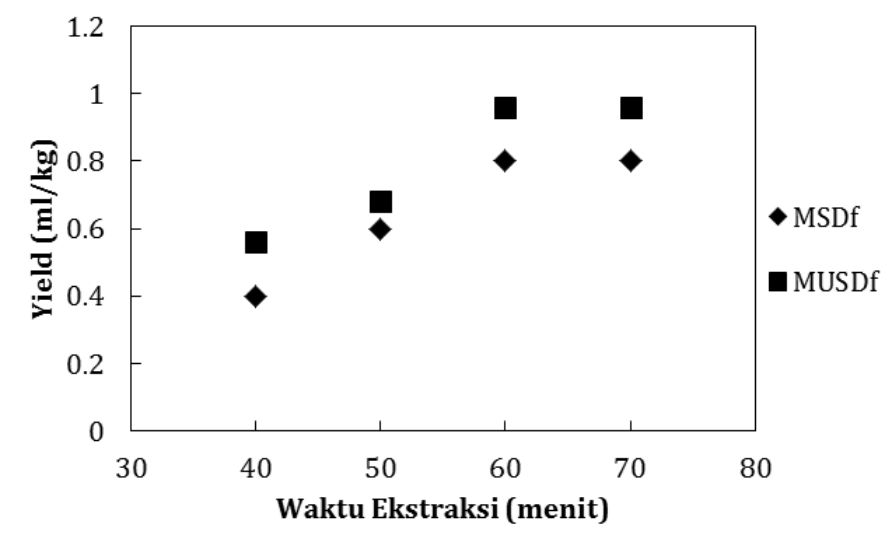

Grafik 1. Yield Minyak Bawang Merah dengan Metode MSDf dan MUSDf

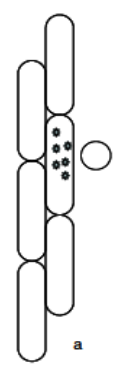

a

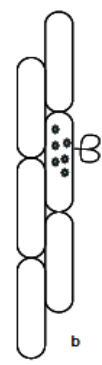

b

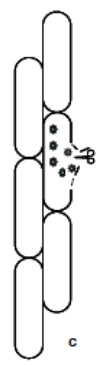

c

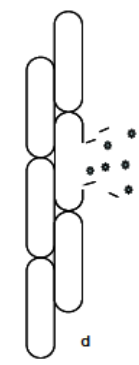

$\mathrm{d}$

Gambar 2. Mekanisme Gelembung Kavitasi 


\subsection{Pengaruh Metode Ekstraksi} terhadap Kualitas Minyak Bawang Merah

Kualitas minyak bawang merah yang dihasilkan menjadi parameter keberhasilan suatu metode ekstraksi. Oleh karena itu produk minyak atsiri yang dihasilkan perlu dilakukan uji Gass Chromatography Mass Spectrometry (GC-MS) utuk mengetahui kadar zat organosulfur yang merupakan bahan aktif dalam bawang merah. Semakin tinggi kadar organosulfur, maka kualitas produk yang dihasilkan semakin baik. Berikut ini merupakan hasil uji GCMS pada minyak bawang merah dengan metode MSDf dan MUSDf yang disajikan pada Gambar 3.

Dari hasil uji GCMS pada Gambar 3 terlihat bahwa minyak bawang merah yang diperoleh dengan metode MSDf (a) pada retention time 4,311 menit terdeteksi senyawa dipropyl disulfide sebesar $17,16 \%$ dan pada retention time 7,320 menit terdeteksi senyawa bis (3-hidroxypropyl) disulfide sebesar 30,93\%. Sedangkan minyak bawang merah yang diperoleh dengan metode MUSDf (b) pada retention time 4,298 menit terdeteksi senyawa dipropyl disulfide sebesar $20,80 \%$ dan pada retention time 7,292 menit terdeteksi senyawa bis (3hidroxypropyl) disulfide sebesar 33,76\%. Data hasil uji GCMS kandungan minyak bawang merah dengan metode MSDf dan MUSDf selengkapnya disajikan pada Tabel 1.

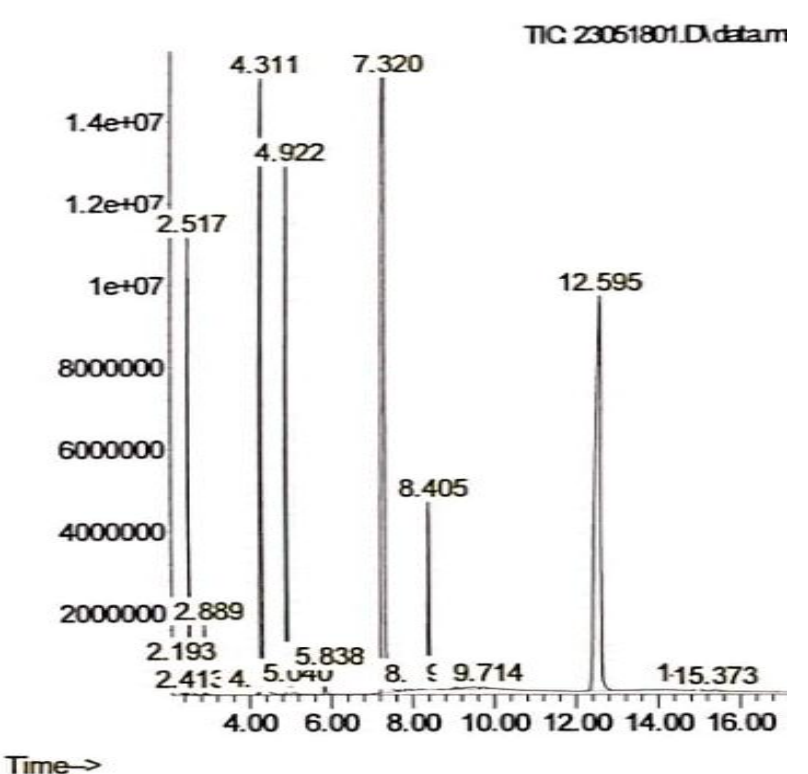

(a)

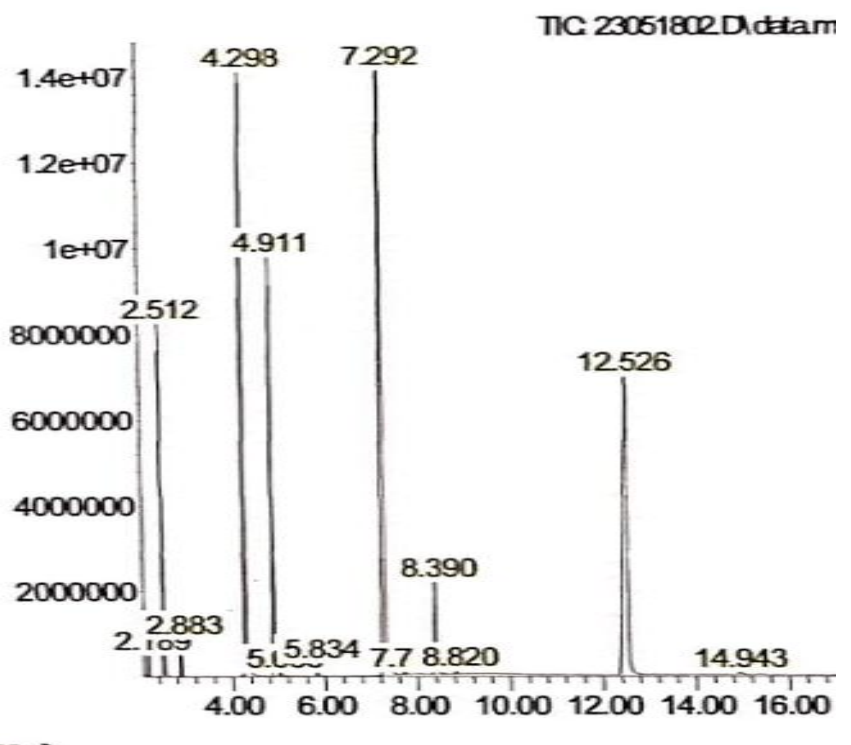

(b)

\section{Gambar 3. Hasil Uji GCMS pada Minyak Bawang Merah dengan Metode MSDf (a)} dan MUSDf (b) 
Hasil uji GCMS pada tabel 1 diatas, terlihat bahwa sebagian besar kandungan minyak bawang merah yang diperoleh dengan metode MSDf dan MUSDf adalah senyawa organosulfur (disufide, trisulfide, tetrasulfide). Hal ini sesuai dengan penelitian Chun-Lin Ye et al. (2012) tentang ekstraksi minyak bawang merah dengan metode Supercritical $\mathrm{CO}_{2}$ Extraction. Dari hasil penelitian tersebut menyatakan bahwa komposisi kimia dari minyak bawang merah hasil analisis GCMS yang paling representatif adalah senyawa organosulfur.

Persentase kandungan organosulfur yang dihasilkan pada metode MSDf dan MUSDf memiliki perbedaan. Persentase kandungan organosulfur pada metode MSDf adalah Bis-3-hydroxypropyl disulfide $(30,93 \%)$, dipropyl disulfide $(17,16 \%)$, methyl propyl disulfide $(5,28 \%)$, dimethyl trisulfide $(0,84 \%)$, dan dimethyl tetrasulfide (0,46\%). Sedangkan pada metode MUSDf, persentase kandungan organosulfur yang dihasilkan yaitu Bis-3-hydroxypropyl disulfide $(33,76 \%)$, dipropyl disulfide (20,80\%), methyl propyl disulfide $(5,61 \%)$, dimethyl trisulfide $(0,63 \%)$, dan dimethyl tetrasulfide $(0,34 \%)$. Apabila senyawa organosulfur tersebut ditotal, diperoleh persentase sebesar $54,67 \%$ untuk metode MSDf dan $61,14 \%$ untuk metode MUSDf. Jika dibandingkan dengan penelitian ChunLin Ye et al. (2012) kandungan organosulfur yang dihasilkan sebesar 56,22\% . Hal ini menunjukkan bahwa penambahan gelombang ultrasonik mampu meningkatkan kadar organosulfur dalam minyak bawang merah.

\section{Tabel 1. Hasil Analisis GCMS Komponen dalam Minyak Bawang Merah}

\begin{tabular}{clcc}
\hline \multirow{2}{*}{ No. Komponen } & \multicolumn{2}{c}{ Metode } \\
\cline { 3 - 4 } & & MSDf (\%) & $\begin{array}{c}\text { MUSDf } \\
(\%)\end{array}$ \\
\hline 1 & Bis-3-Hydroxypropyl & 30,93 & 33,76 \\
2 & Disulfide & 28,94 & 24,51 \\
3 & Pentafluoro Benzene & 17,16 & 20,80 \\
4 & Dipropyl Disulfide & 10,13 & 10,04 \\
5 & Benzoic Acid & 5,28 & 5,61 \\
6 & Methyl Propyl Disulfide & 0,84 & 0,63 \\
7 & Dimethyl Trisulfide & 0,46 & 0,34 \\
8 & Dimethyl Tetrasulfide & 0,40 & 0,23 \\
9 & 1,1-Thiobis Propane & 0,27 & 0,16 \\
10 & 1,3,5-Trithlane & 0,13 & 0,10 \\
\hline
\end{tabular}

DOI: http://dx.doi.org/10.12962/j25493736.v4i2.5093 
Tabel 2. Konsumsi Energi pada Proses Ekstraksi

\begin{tabular}{ccc}
\hline \multirow{2}{*}{ Parameter } & \multicolumn{2}{c}{ Metode } \\
\cline { 2 - 3 } & MSDf & MUSDf \\
\hline Waktu Ekstraksi (jam) & 1 & 1 \\
Waktu Sonifikasi (jam) & - & 0,5 \\
Daya Input Ekstraksi (kW) & 2,25 & 2,25 \\
Daya Input Sonifikasi (kW) & - & 0.03 \\
Total Daya (kWh) & 2,25 & 2,265 \\
Yield (ml/kg) & 0,80 & 0,96 \\
Konsumsi Energi & $\mathbf{2 , 8 1 2}$ & $\mathbf{2 , 3 6 0}$ \\
$(\mathbf{k W h} / \mathbf{m l})$ & & \\
\hline
\end{tabular}

\subsection{Analisis Konsumsi Energi pada}

\section{Proses Ekstraksi}

Analisis konsumsi energi sangat dibutuhkan untuk mengetahui efektivitas dari sebuah metode. Melalui analisis ini energi yang digunakan selama proses ekstraksi dihitung dan dibandingkan dengan produk yang dihasilkan sehingga akan didapatkan berapakah kebutuhan energi per $\mathrm{ml}$ dari produk. Semakin rendah energinya maka semakin efisen metode tersbut. Berikut disajikan tabel 2 yang merupakan perbandingan konsumsi energi dari kedua metode yang digunakan pada penelitian ini.

Dari tabel 2. dapat dilihat bahwa dengan waktu yang sama yaitu 1 jam, energi yang dibutuhkan untuk mendapatkan per $\mathrm{ml}$ minyak bawang merah dari metode MSDf sebesar 2,812 kWh sedangkan untuk metode MUSDf sebesar 2,360 kWh. Melalui data ini bisa disimpulkan bahwa metode MUSDf lebih hemat energi hingga $16 \%$ dibandingkan dengan metode MSDf.

\section{Kesimpulan dan Saran}

Berdasarkan hasil penelitian yang telah dilakukan didapatkan kesimpulan bahwa penambahan gelombang ultrasonik mampu meningkatkan yield minyak bawang merah sebesar $20 \%$ dan mampu meningkatkan kualitas kadar organosulfur minyak bawang merah dari $54,67 \%$ menjadi $61,14 \%$. Jika ditinjau dari energi, penambahan gelombang ultrasonik mempu menurunkan konsumsi energi sebesar $16 \%$.

Melalui penelitian ini dapat terlihat bahwa pengaruh penambahan gelombang ultrasonik cukup signifikan untuk meningkatkan kuantitas dan kualitas dari ekstrak bawang merah. Oleh karena itu perlu dilakukan upaya penelitian lebih lanjut untuk melakukan scaling up dari proses yang telah dilakukan dari penelitian ini sehingga bisa didapatkan hasil yang sama setelah proses scaling up tersebut.

\section{Daftar Pustaka}

[1] Lin, C. M., Sheu, S. R., Hsu, S. C., \& Tsai, Y. H. (2010). Determination of 
Bactericidal Efficacy of Essential Oil

Extracted from Orange Peel on the Food Contact Surfaces. Food Control, 1710-1715.

[2] Muhlizah, F. dan S. Hening-S. 2000. Sayur dan Bumbu Dapur Berkhasiat Obat. Jakarta: Penebar Swadaya.

[3] Eric Block, et al. (1978). Reactions of Organosulfur Compounds. Department of Chemistry, University of Missouri, St. Louis, Missouri. Vol. 37.

[4] Chun-Lin Ye, et al. (2012). Supercritical $\quad \mathrm{CO} 2 \quad$ Extraction Optimization of Onion Oil Using Response Surface Methodology. School of Biological and Chemical Engineering, Zhejiang University of Science and Technology, Hangzhou, China. No.4, 646-652.

[5] Li-Guo Zhang, et al. (2014). Extraction and Quality Analysis of Volatile Oils from Onions by Coupling Pilot and Laboratory Equipment Based on MultiRectification.Separation and Purification Technology.

[6] Khan, M. K., Vian, M. A., Tixier, A. S., Chemat, F., \& Dangles, O. (2010). Ultrasound-Assisted Extraction of Polyphenols (Flavanone Glycosides) from Orange (Citrus sinensis L.) Peel. Food Chemistry, 851-858.
[7] Pratiwi, L., Rachman, M. S. dan Hidayati, N., (2016). Ekstraksi Minyak Atsiri dari Bunga Cengkeh dengan Pelarut Etanol dan N-Heksana. s.l., s.n.

[8] Liu, Q. M., Yang, X. M., Zhang, L., \& Majetich, G. (2010). Optimization of Ultrasonic-Assisted Extraction of Chlorogenic Acid from Folium eucommiae and Evaluation of its Antioxidant Activity. Journal of Medicinal Plants Research Vol. 4 (23), 2503-2511.

[9] Chemat, F., Virot, M., Tamao, V., Ginies, C., \& Visinoni, F. (2008). Green Procedure with a Green Solvent for Fats and Oils Determination: Microwave-integrated Soxhlet Using Limonene Followed by Microwave Clevenger Distillation. Journal of Chromatography A, 147-152.

[10] Garc1'a-Pe'rez, J. V., Ca'rcel, J. A., Fuente-Blanco, S. d. 1. dan Sarabia, E. R.-F., 2006. Ultrasonic Drying of Foodstuff in a Fluidized Bed: Parametric Study. Journal of Ultrasonics, Volume 44, pp. 539-543 